\title{
Expression of ghrelin in human fetal adrenal glands and paraadrenal nerve ganglions
}

\section{Monika Obara-Moszyńska ${ }^{1}$, Andrzej Kędzia ${ }^{1}$, Maria Chmielnicka-Kopaczyk ${ }^{2}$}

${ }^{1}$ II nd Department of Pediatrics Poznań University of Medical Sciences, Poznań, Poland

${ }^{2}$ Department of Biochemistry and Pathology Poznań University of Medical Science, Poznań, Poland

\begin{abstract}
The aim of this paper was assessment of location, expression and role of ghrelin in the development and maturation of human fetal adrenal glands and paraadrenal nerve ganglions. Immunohistochemistry was used. The strongest expression of ghrelin was detected in the fetal zone of the adrenal glands, in the neuroepithelial cells of the medullar portion of the adrenals and in few nerve ganglion cells. Ghrelin takes part in molecular processes of proliferation and maturation, and does not influence on steroidogenesis.
\end{abstract}

Key words: ghrelin, fetal adrenals, nerve ganglions, immunohistochemistry

\section{Introduction}

Ghrelin, an endogenous ligand for GHS-R is a 28 amino acid acylated peptide, isolated for the first time from the mucosal lining of the stomach [1]. Its physiologic role is not fully understood. The presence of ghrelin was observed in different organs of the mature human body including hypothalamus, pituitary gland, pancreas, kidney, lung, heart, intestines, placenta and thyroid gland [2-4]. Ghrelin has been implicated in the release of growth hormone from the pituitary gland and the control of energy homeostasis that regulates the energy consumption by influencing appetite [2]. There is however a relative shortage of knowledge regarding the role a ghrelin in the body of a fetus and newborn. The best know location of ghrelin was shown in the fetal pancreatic islets, while in other organs only its expression has been documented [3,5-7]. The aim of our paper was to assess the location, expression and role of ghrelin in the development and maturation of adrenal glands and paraadrenal nerve ganglions.

\section{Materials and methods}

Adrenal gland specimens. The material included 16 adrenal glands from different periods of the intrauterine life. The charac-

Correspondence: M. Obara-Moszyńska, IInd Dept. of Pediatrics Poznań University of Medical Sciences, Szpitalna 27/33, 60-572 Poznań, Poland; tel.: (+4861) 8491476,

fax.: (+4861) 8480291, e-mail: m.moszynska@neostrada.pl teristics of the fetuses, that the adrenals were taken from, are depicted in Table 1. The embryos and fetuses from the first trimester of pregnancy were embedded as whole in paraffin, and then dissected in the frontal plane, while older fetuses had their adrenal glands isolated and for immunohistochemical staining mainly middle sections of the glands were used.

Immunohistochemistry. For research the antibodies from Santa Cruz Biotechnology Inc were used in a 1:100 dilution. For positive control a sample from pancreas of a 30 week old fetus was taken. In negative control the first antibody was omitted (anti-ghrelin).

\section{Results}

The adrenal gland appears around $5^{\text {th }}$ week of pregnancy, with the embryo measuring $8-10 \mathrm{~mm}$, and is composed of large eosinophilic cells that make up the beginnings of the fetal adrenal cortex. Soon afterwards on the periphery there appears a zone of smaller cells called neocortex that starts the zona glomerulosa of the mature adrenal gland. The adrenal cortex grows rapidly and in the second trimester, constituting $80 \%$ of the adrenal gland mass, and this state continues until birth. In a newborn the fetal zone regresses.

In the adrenal of 5-6 week old fetuses the presence of ghrelin was not observed. However in the organizing nerve ganglions there were few cells with positive granular reaction within the cytoplasm. The origin of these cells is difficult to establish, there could be of neuroepithelial or mesenchymal origins. The first minimal immunoreactions for ghrelin were seen in the cytoplasm of the cells from fetal cortex in $7^{\text {th }}$ week of the embryo life. In the second and third trimester the 
Table 1. The characteristics of adrenal gland donor fetuses, with regard to the week of pregnancy, body weight, length of life and sex.

\begin{tabular}{|c|c|c|c|c|c|}
\hline No. & $\begin{array}{l}\text { Weck of } \\
\text { pregnancy }\end{array}$ & $\begin{array}{l}\text { Body weight } \\
\text { (g) }\end{array}$ & Length of life & Sex & Type of specimens \\
\hline 1 & 5 & $8 \mathrm{~mm}$ & - & - & Whole embryo dissected \\
\hline 2 & 6 & $13 \mathrm{~mm}$ & - & - & Whole embryo dissected \\
\hline 3 & 7 & $13 \mathrm{~mm}$ & - & - & Whole embryo dissected \\
\hline 4 & 10 & $42 \mathrm{~mm}$ & - & $\mathrm{M}$ & Whole fetus dissected \\
\hline 5 & 12 & $50 \mathrm{~mm}$ & - & M & Whole fetus dissected \\
\hline 6 & 14 & 140 & - & li & Whole fetus dissected \\
\hline 7 & 18 & 140 & - & $\mathrm{F}$ & ^drenal gland isolated \\
\hline 8 & 21 & 300 & 1 hour & M & ^drenal gland isolated \\
\hline 9 & 27 & 950 & 7 days & $\mathrm{M}$ & Adrenal gland isolated \\
\hline 10 & 28 & 950 & 2 days & M & Adrenal gland isolated \\
\hline 11 & 31 & 1100 & 14 hours & M & Adrenal gland isolated \\
\hline 12 & 33 & 1655 & 26 days & li & Adrenal gland isolated \\
\hline 13 & 33 & 3200 & 3 days & F & Adrenal gland isolated \\
\hline 14 & 36 & 2920 & 12 hours & $\mathrm{M}$ & Adrenal gland isolated \\
\hline 15 & 36 & 2600 & 19 hours & $\mathrm{M}$ & Adrenal gland isolated \\
\hline 16 & 37 & 1190 & 1 hour & $\mathrm{F}$ & Adrenal gland isolated \\
\hline
\end{tabular}

immunopositive reaction was observed in the whole adrenal cortex. The strongest expression of ghrelin was observed in fetal zone. The reaction was located in the cytoplasm in a form of thick granular, dark yellow precipitate, with negative staining in the nucleus. The expression of immune reaction was similar in the II and III trimesters. In the neocortex zone the expression of ghrelin was weaker and presented as small granular precipitate (Fig. 1). The strongest ghrelin expression in form of dark brown precipitate located in the cytoplasm was observed in the aggregations of neuroepithelial cells placed in the forming medullar portion and in the cortex of the adrenal glands (Fig. 2). The aggregations of cells in the cortex are located there only temporarily, because they will be moved to the medullar portion. First cells of this type were encountered in the adrenals of 14 week old fetuses. In the adrenals of a newborn born in $33^{\text {rd }}$ week of gestation, who survived for 26 days, the expression of ghrelin in the fetal cortex was notably weaker compared to adrenals of newborns from the same pregnancy period that survived for only few hours. More so the staining foci in the fetal zone were of small granular type (Fig. 2)

\section{The paraadrenal nerve ganglions in fetuses}

In the nerve fibers going to the nerve ganglions the ghrelin-like cells were not found. In the nerve gan- glions themselves the satellite cells, lemmocytes and the stromal cells also did not possess ghrelin. A very intensive reaction was observed in few cells scattered within the ganglions. The ganglion cells are a litte immunopositive (Fig. 3).

\section{Discussion}

The knowledge about the role, location and expression of ghrelin and its receptor in fetal tissues compared to mature organisms is particularly week. Only few papers describe the presence of ghrelin in the stomach, thyroid gland, lungs, placenta and other tissues $[3,5,6,8]$. More attention was devoted to ghrelin in the pancreatic islets, where her expression in alpha cells was proven and a role in preserving the energy homeostasis in the fetal body [7]. In our previous paper we have shown the expression of ghrelin and its receptor (GHS-R) in many fetal organs [9]. In available literature we have not found a single paper describing the role, location and expression of ghrelin in developing fetal adrenal glands. There is however quite extensive research on the steroidogenesis processes in the development of fetal adrenals [10-12]. In presented paper we have shown the appearance of ghrelin in fetal zone of the adrenal cortex already at $7^{\text {th }}$ week gestation. With the advance of pregnancy the expression of ghrelin in the growing fetal zone increases, while in 

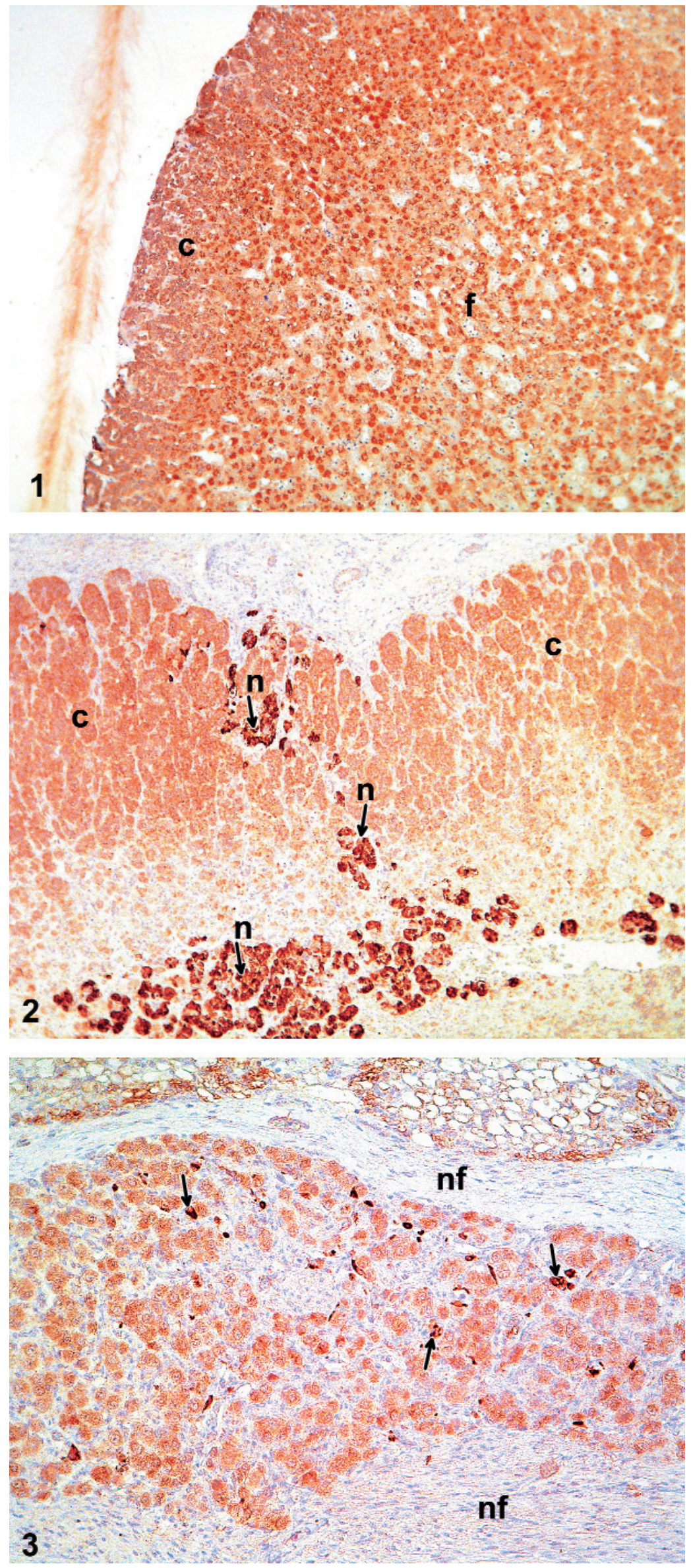

Fig. 1. Adrenal fragment of a 36 week old fetus showing neocortex (c) and fetal zone (f). There is an intensive staining for ghrelin in the fetal zone and weaker in the neocortex (original magnification $\times 200$ ). Fig. 2. An adrenal gland of a 26 day newborn. Visible weak staining in cortex cells (c) and very intensive in neuroepithelial cells (n) deposited in the medullar and cortex portion (arrow) (original magnification $\times 200$ ). Fig. 3. Nerve ganglion. At the bottom of the figure we see a negatively stained nerve fiber (nf). In the ganglion itself a very intense immune staining for ghrelin in few scattered cells (arrow) and weak in ganglion cells is visible (original magnification $\times 200$ ). 
the neocortex the expression was notably weaker. The fetal zone for the whole period of intrauterine life synthesizes mostly dehydroepiandrosterone sulfate (DHEA-S) and its production is greatest in the last weeks preceding labor [11-13]. Whether ghrelin is implicated in the steroidogenesis processes is difficult to establish, although our studies rather rule out such possibility. We have found no correlation between the ghrelin expression and the production of DHEA-S described in the literature; e.g. zona glomerulosa begins production of its specific hormones at the III trimester, while the ghrelin expression is visible in that zone for the whole duration of its differentiation process [12]. We also have not found the increased expression of ghrelin in fetal zone just before initiation of labor. Studies on ghrelin expression in the adrenals of mature rats showed no influence of this peptide on the secretory activity of steroid hormones [14,15]. On the other hand, in vitro studies point to ghrelin influence on the proliferation of the adrenal cells without change in the number of apoptotic cells $[14,15]$. Our research also confirms the influence of ghrelin in molecular processes of proliferation and maturation. In the adrenal glands of a new born from $33^{\text {rd }}$ week gestation, which survived 26 days after birth, the expression of ghrelin was notably weaker, which might indicate, that the process of involution of the fetal zone had already begun and there was a final formation of adrenals. At the same time in those adrenals in the islets of neuroepithelial cells the expression of ghrelin was very strong, and this might suggest, that ghrelin is directly involved in the processes of catecholamines synthesis [16].

Our previous and present research indicates that the strongest ghrelin expression (dark brown to nearly black color reaction) was observed in the cells form pancreatic islets, the neuroepithelial cells of the medullar portion of the adrenals and in few nerve ganglion cells. It was proven that ghrelin plays a direct role in the production of catecholamines in the medullar portion of the adrenals and direct influence on the secretion of insulin in the pancreatic islets $[7,16]$. It was not possible however to show direct involvement of ghrelin in the processes of steroid hormone secretion regulation.

The ghrelin-positive cells described in our paper with very strong expression in the forming ganglions of 6 week old fetuses and mature paraadrenal ganglions are probably of that same origin and they should be included in the cells of diffuse endocrine system. The metabolic role of ghrelin in those cells is not known, and this is the first paper ever that has described such cells in the nerve ganglions.

\section{References}

[ 1] Kojima M, Hosoda H, Date Y, Nakazato M, Matsuo H, Kangawa K. Ghrelin is a growth-hormone-releasing acylated peptide from stomach. Nature. 1999; 402:656-660.

[ 2] Kędzia A, Przybyszewska W. Ghrelina - nowy hormon zaangażowany w regulację wzrastania i homeostazę metaboliczną ustroju. Endokr Pediat. 2007;6:25-29.

[3] Rindi G, Necchi V, Savio A et al. Characterisation of gastric ghrelin cells in man and other mammals: studies in adult and fetal tissues. Histochem Cell Biol. 2002;117:511-519.

[4] Dadan J, Zbucki RL, Sawicki B, Winnicka MM. Estimation of gastric ghrelin-positive cells activity in hyperthyroid rats. Folia Histochem Cytobiol. 2008;46:511-517.

[ 5] Volante M, Fulcheri E, Allia E, Cerrato M, Pucci A, Papotti M. Ghrelin expression in fetal, infant, and adult human lung. J Histochem Cytochem. 2002;50:1013-1021.

[ 6] Volante M, Allia E, Fulcheri E et al. Ghrelin in fetal thyroid and follicular tumors and cell lines: expression and effects on tumor growth. Am J Pathol. 2003;162:645-654.

[ 7] Wierup N, Svensson H, Mulder H, Sundler F. The ghrelin cell: a novel developmentally regulated islet cell in the human pancreas. Regul Pep. 2002;107:63-69.

[ 8] Gualillo O, Caminos J, Blanco M et al. Ghrelin, a novel placental-derived hormone. Endocrinology. 2001;142:788-794.

[ 9] Kędzia A, Chmielnicka-Kopaczyk M, Uklejewska D, ObaraMoszyńska M. Immunohistochemical assessment of ghrelin expression and receptor (GHS-R) in human fetal organs. Arch Perinat Med. 2006;12:12-16.

[10] Rainey WE, Rehman KS, Carr BR. Fetal and maternal adrenals in human pregnancy. Obstet Gynecol Clin North Am. 2004;31:817-835.

[11] Rainey WE, Rehman KS, Carr BR. The human fetal adrenal: making adrenal androgens for placental estrogens. Semin Reprod Med. 2004;22:327-336.

[12] Hammer GD, Parker KL, Schimmer BP. Minireview: transcriptional regulation of adrenocortical development. Endocrinology. 2005;146:1018-1024.

[13] Narasaka T, Suzuki T, Moriya T, Sasano H. Temporal and spatial distribution of corticosteroidogenic enzymes immunoreactivity in developing human adrenal. Mol Cell Endocrinol. 2001;174:111-120.

[14] Carraro G, Albertin G, Abudukerimu A, Aragona F, Nussdorfer GG. Growth hormone secretagogue receptor subtypes 1a and $1 \mathrm{~b}$ are expressed in the human adrenal cortex. Int $J$ Mol Med. 2004;13:295-298.

[15] Andreis PG, Malendowicz LK, Trejter M et al. Ghrelin and growth hormone secretagogue receptor are expressed in the rat adrenal cortex: Evidence that ghrelin stimulates the growth, but not the secretory activity of adrenal cells. FEBS Lett. 2003;536:173-179.

[16] Nanmoku T, Takekoshi K, Ishi K et al. Effect of ghrelin on catecholamine secretion in rat pheochromocytoma PC12 cells. Endocr Res. 2003;29:17-21.

Submitted: 10 October, 2008 Accepted after reviews: 28 December, 2008 